\title{
PEDULI EKOLOGI ALA YESUS DAN PAULUS
}

\author{
Surip Stanislaus*
}

\begin{abstract}
Abstrak
Dalam Kitab Suci Perjanjian Baru sikap Yesus yang peduli ekologi dapat ditemukan dalam pewartaan-Nya tentang Kerajaan Allah. Visimisi hidup Yesus adalah perjuangan demi terwujudnya Kerajaan Allah. Penginjil Yohanes menegaskan bahwa Yesus datang untuk melakukan kehendak Bapa-Nya yang sejak awal mula penciptaan alam semesta menghendaki keharmonian dan keutuhan hidup seluruh ciptaan-Nya, sehingga semuanya diciptakan baik adanya bahkan amat baik (Yoh 5:19,30; 8:26,28,38; Kej 1:10,12,18,21,25,31). Berkaitan dengan keutuhan ciptaan dan harmoni alam, Yesus mewartakan Kerajaan Allah itu lewat perumpamaan-perumpamaan alamiah. Setiap perumpamaan berkenaan dengan kehidupan manusia maupun alam ciptaan yang mengarah pada perbaikan dan pemulihan, keutuhan dan keselamatan. Sebagai contoh Penginjil Matius memaparkan tentang matahari dan hujan yang diperuntukkan bagi orang benar maupun jahat (Mat 5:45) sebagai gambaran kasih Allah yang tanpa pandang bulu dan terbuka untuk semua lapisan dengan bobot yang sama. Penginjil Markus pun menyajikan perumpamaan alamiah, seperti benih yang tumbuh (Mrk 4:26-29), biji sesawi (Mrk 4:30-34) dan pohon Ara (Mrk 13:24-32). Penginjil Lukas juga berbicara tentang perumpamaan yang memakai unsur-unsur alami, seperti awan, hujan, angin dan matahari (Luk 12:5455). Menurut Paulus, Yesus Kristus itulah kebijaksanaan Allah yang dimuliakan karena pencurahan darah-Nya di kayu salib dan kebangkitan-Nya telah membawa pendamaian dan pemulihan keutuhan seluruh alam semesta (Kol 1:15-20). Dengan demikian oleh, untuk, dalam dan dengan Yesus rahasia karya penyelamatan Allah terhadap seluruh ciptaan-Nya telah dinyatakan (Ef 1:9-10). Sebagaimana dalam Kol 1:15-20 karya penyelamatan Allah bagi jemaat terpilih dan seluruh ciptaan terjadi oleh dan menyatu dengan Kristus sebagai Kepala, demikian halnya dalam Ef 1:9-10, bahkan melangkah lebih jauh lagi yakni jemaat dikutsertakan dalam misi penyelamatan Kristus (Ef 3:8-11).
\end{abstract}

\footnotetext{
Surip Stanislaus, Lisensiat dalam bidang Theologi Biblis; lulusan Universitas Gregoriana, Roma; Dosen Kitab Suci pada Fakultas Filsafat Unika St. Thomas, Sumatera Utara.
} 
Kata-kata kunci: peduli ekologi, kerajaan Allah, visi dan misi, keutuhan ciptaan, harmoni alam, perumpamaan alamiah, kebijaksanaan Allah, pencurahan darah, kebangkitan, perdamaian, pemulihan, penyelamatan.

\section{Pengantar}

Kej 1:28 dalam konteksnya sama sekali tidak mengizinkan manusia mengeksploitasi alam tanpa batas, bahkan justru sebaliknya menganjurkan kepedulian terhadap kelestarian ekologi. Alam semesta ciptaan Allah adalah suatu komunitas, di mana setiap bagiannya hanya bisa menjadi sempurna dalam suatu hubungan timbal-balik yang serasi satu dengan yang lain dan semua bagian itu masing-masing mengikuti tujuan yang telah ditentukan baginya oleh Sang Pencipta. Untuk itu berkat yang diterima manusia untuk menaklukkan dan berkuasa atas dunia harus ditempatkan dalam konteks Allah yang mencipta. Dengan kata lain Kej 1:28 dapat ditafsirkan: Allahlah satu-satunya yang punya hak milik dan manusia hanya diberi hak pakai. Artinya, manusia sebagai pemakai harus mengikuti dan patuh pada aturan main yang ditentukan oleh pemilik. Manusia harus bersikap dan memperlakukan dunia sebagaimana Allah bersikap dan memperlakukannya. Oleh karena itu, hendaknya kita bercermin pada Yesus, Imanuel, Allah yang beserta kita, dan salah satu penerus-Nya, yaitu Rasul Paulus.

\section{Yesus dan Kerajaan Allah}

Kitab Suci Perjanjian Baru tidak memaparkan secara eksplisit tindakan Yesus yang peduli ekologi. Sikap Yesus terhadap alam semesta dapat kita temukan dalam kerangka pewartaan-Nya tentang Kerajaan Allah. Kerajaan Allah adalah tata hidup bersama atau komunitas yang diatur oleh nilai-nilai kasih, keadilan dan damai. Sadar akan makna kasih, keadilan dan damai itu Yesus merumuskan kembali hubungan-Nya dengan Yang Ilahi, diri-Nya sendiri, sesama manusia dan dunia-Nya. Yang Ilahi disapa-Nya sebagai Abba, Bapa, suatu relasi intimitas yang sangat mendalam. Sesama dipanggil-Nya sebagai saudara-saudari yang 
ikut berpartisipasi dalam membangun dunia damai. Dunia dirumuskanNya sebagai tempat harmoni untuk berbagi rasa dan cerita. ${ }^{1}$

Visi-misi kehadiran Yesus di dunia adalah penggenapan janji Allah dan perjuangan demi terwujudnya Kerajaan Allah di bumi. Visimisi hidup Yesus adalah perjuangan demi terwujudnya Kerajaan Allah. Misi tersebut menjadi tema sentral seluruh Perjanjian Baru mulai dari Injil-injil hingga Kitab Wahyu. ${ }^{2}$ Penginjil Yohanes menegaskan bahwa Yesus datang untuk melakukan kehendak Allah Bapa-Nya yang sejak awal mula penciptaan alam semesta menghendaki keharmonian dan keutuhan hidup seluruh ciptaan-Nya, sehingga semuanya diciptakan baik adanya bahkan amat baik (Yoh 5:19,30; 8:26,28,38; Kej $1: 10,12,18,21,25,31)$. Dosa manusialah yang telah merusakkan keharmonian dan keutuhan hidup semua ciptaan Allah itu. Akibatnya hubungan manusia dengan Allah terputus, hubungan manusia dengan sesamanya menjadi tidak serasi akibat keegoisan, tidak setia, tamak, iri hati, emosi, dengki, kemarahan, pembunuhan, balas dendam, penindasan, pemerkosaan dan kejahatan, dan hubungan manusia dengan alam maupun lingkungan hidupnya berubah menjadi penguasaan, penaklukan, pengeksploitasian, perampasan dan pemusnahan.

Yesus datang untuk memulihkan kerusakan ketiga demensional akibat dosa manusia itu dengan memaklumkan kegenapan waktu dan kedatangan Kerajaan Allah (Mrk 1:15). Kerajaan Allah itu bermakna sebagai tata kehidupan dan komunitas baru yang tertebus serta menghadirkan keselamatan hic et nunc (here and now), kini dan di sini, yang terus menuju ke kesempurnaannya di masa mendatang. Kesempurnaan keselamatan di masa depan itu berkaitan dengan pemulihan hubungan dan tata ciptaan baru yang dalam bahasa apokaliptik disebut langit dan bumi baru (Why 21:1-10) yang berpusat pada

\footnotetext{
${ }^{1}$ V. Visick, "Creation's care and keeping in the life of Jesus," dalam C.B. DeWitt, ed., The Environment and the Christian: What does the New Testament say about the Environment? (Grand Rapids: Baker Book House, 1991), hlm. 95.

2 G. Zerbe, "The Kingdom of God and Stewardship of Creation," dalam C.B. DeWitt, ed., The Environment and the Christian: What does the New Testament say about the Environment? (Grand Rapids: Baker Book House, 1991), hlm. 74.
} 
Yerusalem baru (Why 21:9-22:5). Pemulihan keutuhan dan keharmonian seluruh ciptaan itulah yang sudah hadir dalam hidup dan karya Yesus. ${ }^{3}$

Berkaitan dengan keutuhan ciptaan dan harmoni alam, Yesus mewartakan Kerajaan Allah lewat perumpamaan-perumpamaan alamiah. Setiap perumpamaan tentang Kerajaan Allah berkenaan dengan kehidupan manusia maupun alam ciptaan yang mengarah pada perbaikan dan pemulihan, keutuhan dan keselamatan. Kitab Suci Perjanjian Baru melukiskan beragam pewartaan Yesus yang mengacu pada terciptanya komunitas kasih, keadilan dan damai itu lewat beragam perumpamaan alamiah. ${ }^{4}$

Penginjil Matius memaparkan berbagai contoh. Matahari dan hujan yang bukan diperuntukkan bagi golongan tertentu saja tetapi bagi semua, baik orang yang benar maupun yang jahat (Mat 5:45) merupakan gambaran kasih Allah yang tanpa pandang bulu dan terbuka bagi semua lapisan dengan bobot yang sama. Sedangkan dengan keadilan Allah yang dikisahkan lewat kilat yang memancar dan burung nazar (Mat 24:27-28), Yesus mau menunjukkan datangnya kekacauan, kebobrokan moral akibat gagal mencinta, sehingga damai pun tiada terwujud. Dengan perumpamaan tentang burung-burung di langit yang tidak menabur dan menuai tetapi diberi makan dan bunga-bunga bakung di ladang yang tumbuh mempesona tanpa bekerja dan memintal (Mat 6:25-34), Yesus mengumandangkan nasihat agar tidak cemas dan penyerahan total kepada penyelenggaraan Allah. Sementara itu melalui perumpamaan tentang ngegat dan karat terhadap harta duniawi (Mat 6:19-21), Yesus mengajarkan sikap ketidaklobaan hati.

Penginjil Markus pun menyajikan perumpamaan-perumpamaan alamiah, misalnya perumpamaan tentang benih yang tumbuh (Mrk 4:2629), biji sesawi (Mrk 4:30-34) dan pohon Ara (Mrk 13:24-32). Sedangkan Penginjil Lukas juga berbicara tentang Kerajaan Allah dengan

\footnotetext{
${ }^{3}$ G. Zerbe, "The Kingdom...," hlm. 78, 84.

${ }^{4}$ R. Bauckham, "Jesus and the wild animals (Mark 1:13): A christological image for an ecological age," dalam J.B. Green and M. Turner, eds., Jesus of Nazareth: Lord and Christ: Essays on the Historical Jesus and New Testament Christology (Grand Rapids: Eerdmans, 1994), hlm. 19.
} 
perumpamaan yang memakai unsur-unsur alami, seperti awan, hujan, angin dan matahari (Luk 12:54-55).

Dengan perumpamaan tentang Kerajaan Allah yang mengangkat aneka unsur alamiah menunjukkan bahwa Yesus sangat dekat dengan alam. Kedekatan dengan anasir-anasir alam ini yang menimbulkan rasa cinta dan hormat-Nya terhadap jagad raya beserta isinya. Rasa cinta itulah yang menumbuhkan sikap mau menjaga, memelihara dan selflimitation atau membatasi diri dalam menggunakan sumber daya alam. Dunia memiliki batas kemampuan tertentu sehingga eksploitasi alam tanpa batas harus dihentikan dan digalakkan harmonisasi alam. Dengan demikian dunia sebagai tempat harmoni untuk berbagi rasa dan cerita setiap makhluk akan terwujud. ${ }^{5}$

\section{Rasul Paulus dan Madah Kristologis}

Mazhab Rasul Paulus mewartakan Yesus sebagai kebijaksanaan Allah yang dimuliakan karena pencurahan darah-Nya di kayu salib dan kebangkitan-Nya membawa pendamaian dan pemulihan keutuhan seluruh alam semesta. Warta Yesus sebagai kebijaksanaan Allah itu tercatat dalam Kol 1:15-20. ${ }^{6}$

${ }^{15}$ Ia adalah gambar Allah yang tidak kelihatan, yang sulung, lebih utama dari segala yang diciptakan, ${ }^{16}$ karena di dalam Dialah telah diciptakan segala sesuatu, yang ada di surga dan yang ada di bumi, yang kelihatan dan yang tidak kelihatan, baik singgasana, maupun kerajaan, baik pemerintah, maupun penguasa; segala sesuatu diciptakan oleh Dia dan untuk Dia. ${ }^{17}$ Ia ada terlebih dahulu dari segala sesuatu dan segala

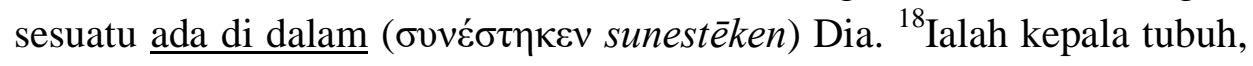
yaitu jemaat. Ialah yang sulung ( (’’ $\chi \eta ́ ~ a r k h \bar{e})$ bangkit dari antara orang mati, sehingga Ia yang lebih utama dalam segala sesuatu. ${ }^{19}$ Karena seluruh kepenuhan Allah berkenan

\footnotetext{
${ }^{5}$ S. Surip, Harmoni Kehidupan. Asal-usul Alam Semesta. Menggembalakan Ciptaan (Yogyakarta: Kanisius, 2008).

6 P. Stuhlmacher, "The ecological crisis as a challenge for biblical theology," dalam Ex Auditu 3 (1987), hlm. 8-18. Ibr 1:2b-3a juga menekankan peran Yesus yang dengan-Nya Allah menciptakan alam semesta: "Oleh Dia Allah telah menjadikan alam semesta. Ia adalah cahaya kemuliaan Allah dan gambar wujud Allah dan menopang segala yang ada dengan firman-Nya yang penub kekuasaan."
} 
diam di dalam Dia, ${ }^{20}$ dan oleh Dialah Ia memperdamaikan segala sesuatu dengan diri-Nya, baik yang ada di bumi, maupun yang ada di surga, sesudah Ia mengadakan pendamaian oleh darah salib Kristus.

Sebagian besar ahli Kitab Suci sepakat bahwa perikop di atas merupakan saduran dari madah kuno tentang teologi penciptaan dengan penambahan "yaitu jemaat" dalam ayat 18 dan "oleh darah salib Kristus" di ayat 20. Penambahan tersebut membuat madah ini menjadi madah Kristologis yang menegaskan peranan Kristus dalam memperdamaikan jemaat dengan Allah melalui kematian-Nya di salib. Madah ini terdiri dari dua bait yang bergerak dari tema penciptaan segala sesuatu oleh dan dalam Kristus (ayat 15-17, bait pertama) menuju ke tema pendamaian seluruh alam semesta dalam Kristus (ayat 18-20, bait kedua).

Bait pertama yang diawali dengan memperkenalkan Yesus sebagai "gambar Allah" kiranya merujuk pada kebijaksanaan Israel dalam Keb 7:26, "Kebijaksanaan merupakan pantulan cahaya kekal, dan cermin tak bernoda dari kegiatan Allah, dan gambar kebaikan-Nya." Maksudnya sama seperti kebijaksanaan merupakan pantulan dari Allah, demikian halnya dengan Kristus (bdk. 2Kor 4:6). ${ }^{7}$ Sebagaimana kebijaksanaan dalam Ams 8:30 dilukiskan dengan anak kesayangan (atau mandor $)^{8}$ yang menyertai Allah saat menciptakan langit dan bumi, serta anak itu senang tinggal di tengah-tengah orang yang mencarinya (Ams

\footnotetext{
7 Allah yang telah berfirman: "Dari dalam gelap akan terbit terang!," Ia juga yang membuat terang-Nya bercahaya di dalam hati kita, supaya kita beroleh terang dari pengetahuan tentang kemuliaan Allah yang nampak pada wajah Kristus (2Kor 4:6).

${ }^{8}$ D. Edwards, Jesus the Wisdom of God: An Ecological Theology (Maryknoll: Orbis, 1995), hlm. 19-87. Kata Ibrani 'mwn menimbulkan kesulitan, karena dapat dibaca dengan àmôn yang berarti “arsitek, mandor" atau àmûn yang berarti “anak kesayangan”. Dalam konteks dekat (8:30bc-31) maupun konteks jauh (8:22-24) 'mwn harus diterjemahkan dengan "anak kesayangan", sehingga kebijaksanaan digambarkan seperti putri kesayangan TUHAN yang senang mengamati dan kagum akan pekerjaan TUHAN serta membuat-Nya senang (8:30b). Namun dalam Septuaginta (LXX) terjemahan Yunani mengikuti vokalisasi 'ommān yang berarti arsitek, mandor. Pada hal kata 'ommān itu serapan dari kata Akkad ummanu yang dalam mitologi Mesopotamia bukan arsitek, mandor, melainkan orang bijak yang membawa hikmat, budaya dan keahlian dari dunia ilahi bagi umat manusia. Orang bijak yang membawa hikmat ilahi bagi manusia ini lebih cocok dengan Ams 8:30 dari pada anak kesayangan yang bermain-main di hadapan TUHAN. Jadi, kebijaksanaan digambarkan seperti putri bijak yang mendampingi TUHAN sewaktu Ia menciptakan langit, laut dan bumi serta senang melihatnya, lalu hadir di bumi dan senang terlebih karena tinggal di tengah-tengah orang yang mencarinya.
} 
8:31), demikian halnya dengan Kristus Yesus, Putera Allah yang terkasih dan menjadi Imanuel, Allah yang tinggal beserta kita. ${ }^{9}$

Kitab Amsal mengidentikkan hikmat kebijaksanaan dengan firman: "Dengan hikmat TUHAN telah meletakkan dasar bumi" (Ams 3:19). Bagi orang Yahudi, firman bukanlah sekedar kata-kata, tetapi sesuatu yang berdaya cipta, MEMBERI hidup dan menghasilkan. Perjanjian Lama banyak menyajikan ide tentang firman yang kreatif dan produktif, yang berdaya cipta dan menghasilkan: "Berfirmanlah Allah: Jadilah terang. Lalu terang itu jadi” (Kej 1:3 bdk. Kej 1:6,9,11,14,20,24,26,29); "Oleh firman TUHAN langit telah dijadikan" (Mzm 33:6); "Disampaikan-Nya firman-Nya dan disembuhkan-Nya mereka" (Mzm 107:20); "Demikianlah firman-Ku yang keluar dari mulut-Ku; ia tidak akan kembali kepada-Ku dengan sia-sia, tetapi akan melaksanakan apa yang Kukehendaki, dan akan berhasil dalam apa yang Kusuruhkan kepadanya" (Yes 55:11).

Hikmat kebijaksanaan yang identik dengan firman Allah itu pun dipersonifikasikan sebagai "aku" dan telah ada bersama Allah sejak awal mula serta menyenangkan-Nya (Ams 8:22-30).

${ }^{22}$ TUHAN telah menciptakan aku sebagai permulaan pekerjaanNya, sebagai perbuatan-Nya yang pertama-tama dahulu kala. ${ }^{23}$ Sudah zaman purbakala aku dibentuk, pada mula pertama, sebelum bumi ada [...]. ${ }^{27}$ Ketika Ia mempersiapkan langit, aku di sana [...], ${ }^{29}$ ketika Ia menetapkan dasar-dasar bumi, ${ }^{30}$ aku ada serta-Nya sebagai anak kesayangan, setiap hari aku menjadi kesenangan-Nya, dan senantiasa bermain-main di hadapan-Nya.

Kebijaksanaan yang diidentikan dengan Firman Allah dan dipersonifikasikan ${ }^{10}$ itu sama halnya dengan Yesus. Kitab Ams 8 tersebut

\footnotetext{
${ }^{9}$ Pada saat dibaptis di sungai Yordan oleh Yohanes Pembaptis terdengarlah suara Allah dari sorga yang memperkenalkan Yesus di hadapan publik: "Engkaulah Anak-Ku yang Kukasibi, kepada-Mulah Aku berkenan” (Mrk 1:11//Mat 3:17//Luk 3:22).

10 Kitab Amsal mengidentikkan kebijaksanaan/hikmat dengan firman: "Dengan bikmat TUHAN telah meletakkan dasar bumi...” (Ams 3:19). Bagi orang Yahudi, firman bukanlah sekedar kata-kata, tetapi sesuatu yang berdaya cipta, memberi hidup dan menghasilkan. Perjanjian Lama banyak menyajikan ide tentang firman yang kreatif dan produktif, yang berdaya cipta dan menghasilkan: "Berfirmanlah Allab: Jadilah terang. Lalu terang itu jadi" (Kej 1:3 bdk. Kej 1:6,9,11,14,20,24,26,29); “Oleh firman TUHAN langit telah dijadikan” (Mzm
} 
telah membantu jemaat Kristen untuk meyakini bahwa Yesus yang dalam pengajaran dan tindakan-Nya tampil sebagai orang berhikmat dan guru kebijaksanaan itu adalah "hikmat Allah" (1Kor 1:24). ${ }^{11}$ Identifikasi Yesus dengan hikmat inilah yang memungkinkan segala sesuatu yang ada di langit maupun di bumi diciptakan oleh Dia, untuk Dia dan ada di

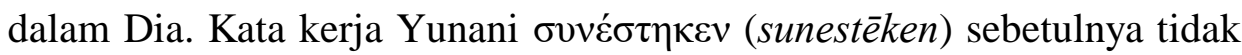
cukup diterjemahkan dengan "ada di dalam" saja, tetapi harus lebih tegas lagi dengan "menyatu dengan", suatu hubungan relasional yang sangat mendalam. $^{12}$

Hikmat/kebijaksanaan Allah yang sejak semula sudah ada dan hadir aktif dalam karya penciptaan Allah serta kini sudah datang dan kesenangannya tinggal di tengah-tengah manusia di bumi itulah yang diperkenalkan Penginjil Yohanes dengan Yesus (Yoh 1:1-3,14).

${ }^{1}$ Pada mulanya adalah Firman; Firman itu bersama-sama dengan Allah dan Firman itu adalah Allah. ${ }^{2}$ Ia pada mulanya bersama-sama dengan Allah. ${ }^{3}$ Segala sesuatu dijadikan oleh Dia dan tanpa Dia tidak ada suatupun yang telah jadi dari segala yang telah dijadikan. ${ }^{14}$ Firman itu telah menjadi manusia, dan diam di antara kita, dan kita telah melihat

33:6); "Disampaikan-Nya firman-Nya dan disembubkan-Nya mereka" (Mzm 107:20); "Demikianlah firman-Ku yang keluar dari mulut-Ku; ia tidak akan kembali kepada-Ku dengan sia-sia, tetapi akan melaksanakan apa yang Kukehendaki, dan akan berhasil dalam apa yang Kusurubkan kepadanya" (Yes 55:11). Kebijaksanaan itu pun dipersonifikasikan sebagai "aku" dan telah ada bersama Allah sejak awal mula serta menyenangkan-Nya: "TUHAN telah menciptakan aku sebagai permulaan pekerjaan-Nya, sebagai perbuatan-Nya yang pertama-tama dabulu kala. Sudah zaman purbakala aku dibentuk, pada mula pertama, sebelum bumi ada... Ketika Ia mempersiapkan langit, aku di sana... ketika Ia menetapkan dasar-dasar bumi, aku ada serta-Nya sebagai anak. kesayangan, setiap hari aku menjadi kesenangan-Nya, dan senantiasa bermain-main di hadapanNya...” (Ams 8:22-30).

${ }^{11}$ D. Edwards, Jesus the Wisdom..., hlm. 45-50. Hubungan antara hikmat/kebijaksanaan yang lebih unggul atas segala ciptaan dan jaraknya dengan Allah dilukiskan terutama lewat katakata kerja dalam Ams 8:22-24 "menciptakan", "membentuk", "melahirkan", serta kata "pekerjaan-Nya" dan "perbuatan-Nya". Lewat kata "diciptakan" dan "dibentuk", hikmat disamakan dengan segala ciptaan lainnya, tetapi punya keunggulan yang bukan sekedar prioritas waktu melainkan juga mutu, sebagai "permulaan pekerjaan-Nya" dan "perbuatanNya yang pertama-tama dahulu kala". Sedangkan dengan kata "dilahirkan", hikmat dibedakan dengan segala ciptaan lainnya, karena kata dilahirkan mengungkapkan hubungan ekslusif antara hikmat dengan Allah.

${ }^{12}$ Makna kata kerja sunestèken nampak dalam perkataan "mempersatukan segala sesuatu di dalam Kristus sebagai Kepala” (Ef 1:10). 
kemuliaan-Nya, yaitu kemuliaan yang diberikan kepada-Nya sebagai Anak Tunggal Bapa, penuh kasih karunia dan kebenaran.

Istilah "pada mulanya" dalam "Pada mulanya adalah Firman" (Yoh 1:1) searti dengan "pada mulanya" dalam "Pada mulanya Allah menciptakan langit dan bumi" (Kej 1:1). Istilah "pada mulanya" tidak menunjuk pada titik waktu tertentu, tetapi kekekalan yang tidak mengenal periode waktu dan sudah berada sebelum adanya waktu. Jadi, Firman itu tidak berada pada titik waktu atau periode waktu tertentu, tetapi kekal adanya. Firman yang kekal itu mempribadi dan bersamasama dengan Allah. Artinya, Firman itu berelasi dan dalam kesetaraan dengan Allah, sehingga berhakekat ilahi. Oleh karena itu, Firman memiliki dan memanifestasikan hakekat Allah secara kekal, sehingga Firman itu pun adalah Allah. ${ }^{13}$

Firman itu bersama-sama dengan Allah pada permulaan segala sesuatu. "Segala sesuatu" dimaksudkan dengan alam semesta, unsurunsurnya dan sistem-sistem hukumnya. Segala sesuatu itu dijadikan oleh Dia: "Segala sesuatu dijadikan oleh Dia dan tanpa Dia tidak ada suatupun yang telah jadi dari segala yang telah dijadikan" (Yoh 1:3). Artinya, semua ciptaan adalah produk dari Firman yang menjadi perantara dan pelaksana karya penciptaan Allah. Kata "dijadikan" menyiratkan suatu transisi dari yang sebelumnya tidak ada menjadi ada, sehingga semua ciptaan sifatnya sementara.

Firman itu datang ke dunia dengan inkarnasi: "Firman itu telah

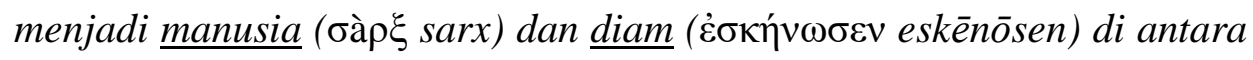
kita" (Yoh 1:14a). Firman itu menjelma dan menyatakan diri dalam pribadi manusia yang kelihatan. Artinya, Ia ambil bagian dalam darah dan daging manusia dengan keterbatasan ruang dan waktu (dilahirkan di tempat dan waktu tertentu) serta kendala-kendala fisik seperti rapuh,

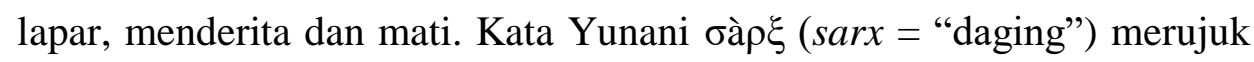
pada hakekat manusia dalam segala keterbatasan dan

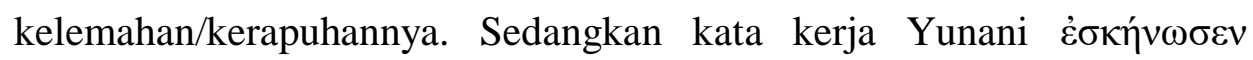
(eskēnōsen) yang diterjemahkan dengan "diam" sebenarnya artinya "membuat kemah." Sebagaimana kemah itu bukan tempat tinggal

${ }^{13}$ S. Surip, "Rahasia di Balik Kisah Natal 2" (Yogyakarta: Kanisius, 2007), hlm. 76-77. 
permanen dan hanya sementara, demikian halnya Firman itu hadir dan berkemah di antara kita dalam diri Yesus untuk sementara waktu dan tidak bersifat kekal. Ia dilahirkan, menjalani masa kanak-kanak, berkarya, sengsara, wafat, dibangkitkan dan naik ke surga. Dalam diri Yesus, Allah datang ke bumi dan tinggal beserta umat manusia untuk sementara waktu lalu kembali ke surga. Karena penjelmaan Firman yang berkemah di antara kita itulah "kita telah melihat kemuliaan-Nya, yaitu kemuliaan yang diberikan kepada-Nya sebagai Anak Tunggal Bapa, penuh kasih karunia dan kebenaran" (Yoh 1:14b). ${ }^{14}$

Berkat penjelmaan Firman yang berkemah di antara kita itu, meskipun hakekat keilahian Allah belum pernah secara langsung diperlihatkan kepada manusia, kini Allah yang tidak kelihatan dan misteri itu dapat dilihat dalam Anak Tunggal-Nya. Sebab Anak adalah cerminan yang sempurna dari kehidupan dan kasih Bapa. Demikianlah Allah, melalui Anak-Nya telah menyatakan diri-Nya kepada manusia. Kata "menyatakan" searti dengan mewahyukan, yang mengandung makna "penyingkapan atau penguraian rahasia-rahasia ilahi." Firman yang menjadi manusia dan diam di antara kita adalah rumusan teologis yang searti dengan Imanuel, "Allah beserta kita.,"15

Yesus yang adalah kebijaksanaan dan firman Allah, anak kesayangan atau orang bijak yang hadir dan dengan perantaraannya segala sesuatu diciptakan, dan kini telah datang serta tinggal di tengahtengah manusia sebagai Imanuel itulah inti dari bait pertama madah Kristologis. Firman/kebijaksanaan Allah yang turut serta dalam penciptaan segala sesuatu dengan baik adanya itulah yang telah menjelma dalam diri Yesus dan tinggal di antara kita. Dengan demikian inkarnasi bukan hanya dilihat sebagai alasan untuk penebusan dan penyelamatan manusia yang sudah jatuh ke dalam dosa, tetapi bahkan diperlukan untuk pemulihan keutuhan dan keharomian relasi segala ciptaan: "Karena begitu besar kasih Allah akan dunia ini, sehingga Ia telah mengaruniakan Anak-Nya yang tunggal" (Yoh 3:16).

\footnotetext{
${ }^{14}$ S. Surip, "Rahasia di Balik..." hlm. 78.

15 S. Surip, "Rahasia di Balik..." hlm. 78-79.
} 
Rasul Paulus telah memperkenalkan Yesus bukan hanya sebagai hikmat Allah (1Kor 1:24) yang dengan perantaraan-Nya segala sesuatu diciptakan (1Kor 8:6), tetapi juga hikmat tersembunyi dan rahasia, yaitu rencana penyelamatan Allah: "Yang kami beritakan ialah hikmat Allah yang tersembunyi dan rahasia, yang sebelum dunia dijadikan, telah disediakan Allah bagi kemuliaan kita" (1Kor 2:7). Hikmat Allah yang tersembunyi dan rahasia itu baru tersingkap dalam diri Yesus karena berkenaan dengan Yesus yang tersalib (1Kor 1:23-24).

${ }^{23}$ Kami memberitakan Kristus yang disalibkan: untuk orang-orang Yahudi suatu batu sandungan dan untuk orang-orang bukan Yahudi suatu kebodohan, ${ }^{24}$ tetapi untuk mereka yang dipanggil, baik orang Yahudi, maupun orang bukan Yahudi, Kristus adalah kekuatan Allah dan hikmat Allah.

Mengapa Kristus yang disalibkan dan dipandang sebagai batu sandungan dan kebodohan itu dapat disebut kekuatan dan hikmat Allah? Kematian Yesus yang disalibkan menjadi bukti kasih yang ekstrim, sulit dinalar dan tak tersangkalkan. Kasih Yesus yang dengan rela mencurahkan darah-Nya hingga mati di kayu salib itu telah memperdamaikan segala sesuatu baik yang di bumi maupun yang di sorga dengan Allah. Maka, kasih yang begitu nyata dalam kematian Yesus di salib dan mendatangkan keselamatan bagi semua ciptaan itu jelas telah menunjukkan hikmat dan kekuatan Allah. ${ }^{16}$

Peran Yesus yang dengan kasih-Nya telah mencurahkan darah hingga mati di kayu salib demi mendamaikan semua ciptaan terutama jemaat dengan Allah itulah inti dari bait kedua madah Kristologis.

${ }^{18}$ Ialah kepala tubuh, yaitu jemaat. Ialah yang sulung ( $\pi \rho \omega \tau$ tó

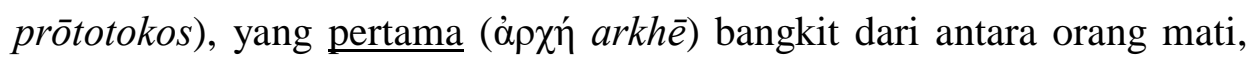
sehingga Ia yang lebih utama dalam segala sesuatu. ${ }^{19}$ Karena seluruh kepenuhan Allah berkenan diam di dalam Dia, ${ }^{20}$ dan oleh Dialah Ia memperdamaikan segala sesuatu dengan diri-Nya, baik yang ada di bumi, maupun yang ada di surga, sesudah Ia mengadakan pendamaian oleh darah salib Kristus.

${ }^{16}$ Harun, M. "Paulus dan Penyelamatan Kosmos," dalam Forum Biblika 14 (2001), hlm. 70. 


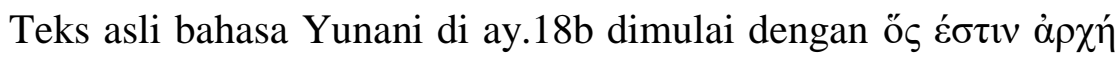
(hos estin arkhē = ia adalah permulaan). Sebutan Yesus sebagai ả $\rho \chi \eta ́$ (arkhē = permulaan) merujuk pada Yesus yang adalah hikmat kebijaksanaan Allah: "TUHAN telah menciptakan aku sebagai permulaan pekerjaan-Nya, sebagai perbuatan-Nya yang pertama-tama dahulu kala. Sudah pada zaman purbakala aku dibentuk, pada mula pertama, sebelum bumi ada" (Ams 8:22-23). Sedangkan kata $\pi \rho \omega \tau$ б́́коธ (prōtotokos = yang pertama lahir atau sulung) bukan dikenakan pada yang pertama dari penciptaan, tetapi yang pertama lahir/bangkit dari antara orang mati. Jadi, Yesus juga yang pertama dari kebangkitan orang mati, awal dan dasar bagi kehidupan baru yang berlaku bukan hanya untuk jemaat tetapi juga untuk segala sesuatu yang telah diciptakan dengan perantaraan-Nya. Dengan kata lain jangkauan karya penyelamatan Allah melalui Yesus seluas segala kenyataan. Segala sesuatunya, baik yang di surga maupun yang di bumi, semua yang diciptakan oleh, dalam dan untuk Yesus turut mengalami penyelamatanNya karena semuanya telah menyatu dengan Dia. ${ }^{17}$

Dengan demikian Yesus, hikmat Allah yang menjadi awal dan model dengan-Nya segala sesuatu atau alam semesta beserta segala isinya diciptakan, kepada Dia juga arah tujuan semua ciptaan, "karena seluruh kepenuhan Allah berkenan diam di dalam Dia." Yesus itu juga arah tujuan, kepenuhan dan keutuhan segala sesuatu atau semua ciptaan Allah, termasuk singgasana maupun kerajaan, pemerintah maupun penguasa, karena oleh Dia dan dengan darah-Nya yang tercurah di salib hingga kematian-Nya Allah memperdamaikan segala ciptaan dengan diri-Nya. Dengan darah dan kematian-Nya di salib Yesus telah mendamaikan, menyambung kembali hubungan yang putus dan mempersatukan segala sesuatu dengan Allah. Dengan darah dan kematian-Nya di salib Yesus telah memulihkan keutuhan semua ciptaan dan keharmonian relasi mereka dengan Allah, sesama dan ciptaan lainnya. Kesimpulannya, oleh, untuk, dalam dan dengan Yesus rahasia hikmat Allah, yaitu rancangan karya penyelamatan-Nya terhadap seluruh ciptaan-Nya, telah dinyatakan (Ef 1:9-10).

\footnotetext{
${ }^{17}$ D. Edwards, Jesus the Wisdom..., hlm. 81.
} 
${ }^{9}$ Sebab Ia telah menyatakan rahasia kehendak-Nya kepada kita, sesuai dengan rencana kerelaan-Nya, yaitu rencana kerelaan yang dari semula telah ditetapkan-Nya di dalam Kristus ${ }^{10}$ sebagai persiapan kegenapan waktu untuk mempersatukan di dalam Kristus sebagai Kepala segala sesuatu, baik yang di sorga maupun yang di bumi.

Sebagaimana dalam Kol 1:15-20 bahwa karya penyelamatan Allah bagi jemaat/orang-orang terpilih dan seluruh ciptaan terjadi oleh dan menyatu dengan Kristus sebagai Kepala, demikian halnya dalam Ef 1:9-10, bahkan melangkah lebih jauh lagi bahwa jemaat itu dikutsertakan dalam misi penyelamatan Kristus (Ef 3:8-11). ${ }^{18}$

${ }^{8}$ Kepadaku, yang paling hina di antara segala orang kudus, telah dianugerahkan kasih karunia ini, untuk memberitakan kepada orangorang bukan Yahudi kekayaan Kristus, yang tidak terduga itu, ${ }^{9}$ dan untuk menyatakan apa isinya tugas penyelenggaraan rahasia yang telah berabad-abad tersembunyi dalam Allah, yang menciptakan segala sesuatu, ${ }^{10}$ supaya sekarang oleh jemaat diberitahukan pelbagai ragam hikmat Allah kepada pemerintah-pemerintah dan penguasa-penguasa di sorga, ${ }^{11}$ sesuai dengan maksud abadi, yang telah dilaksanakan-Nya dalam Kristus Yesus, Tuhan kita.

\section{Kesimpulan}

Para penulis surat dan buku Perjanjian Baru tidak banyak menyinggung soal iman bangsa Israel tentang Allah Pencipta alam semesta dan segala isinya, tetapi iman itu juga yang sepenuhnya diandaikan. Mereka bukan bermaksud mengganti Perjanjian Lama, tetapi mau melengkapinya dengan mengembangkan dan mengartikan ulang kesaksian iman bangsa Israel akan Allah Pencipta itu dalam peran Yesus Kristus.

Janji tentang langit dan bumi yang baru dalam 2Ptr 3 dan Why 21 pun merupakan janji yang telah dinubuatkan Nabi Yesaya (Yes 65). Penggenapan janji dan perwujudan langit dan bumi yang baru itu sudah nampak dalam visi dan misi pewartaan Yesus tentang Kerajaan Allah. Peran Yesus dalam karya penyelamatan universal demi terwujudnya

18 J.G. Gibbs, "Pauline cosmic Christology and ecological crisis," dalam Journal of Biblical Literature 90 (1971), hlm. 474-475. 
kembali harmoni alam dan keutuhan ciptaan itulah yang menjadi pokok permenungan dan pengajaran Rasul Paulus dan mazhabnya. Nah, kalau Yesus saja berjuang dewi terwujudnya kembali harmoni alam dan keutuhan ciptaan, maka kita pun sebagai murid-murid-Nya, seperti bangsa Israel, diajak juga untuk peduli ekologi, mengolah dan memelihara bumi yang sekarang dipercayakan kepada kita.

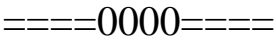

\section{DAFTAR PUSTAKA}

Bauckham, R. "Jesus and the wild animals (Mark 1:13): A christological image for an ecological age," dalam J.B. Green and M. Turner, eds., Jesus of Nazareth: Lord and Christ: Essays on the Historical Jesus and New Testament Christology. Grand Rapids: Eerdmans, 1994.

Edwards, D. Jesus the Wisdom of God: An Ecological Theology. Maryknoll: Orbis, 1995.

Gibbs, J.G. "Pauline cosmic Christology and ecological crisis," dalam Journal of Biblical Literature 90 (1971), hlm. 466-479.

Harun, M. "Paulus dan Penyelamatan Kosmos," dalam Forum Biblika 14 (2001), hlm. 67-85.

Stuhlmacher, P. "The ecological crisis as a challenge for biblical theology," dalam Ex Auditu 3 (1987).

Surip, S. Harmoni Kehidupan. Asal-usul Alam Semesta. Menggembalakan Ciptaan. Yogyakarta: Kanisius, 2008. 
. Rahasia di Balik Kisah Natal 2. Yogyakarta: Kanisius. 2007.

Visick, V. "Creation's care and keeping in the life of Jesus," dalam C.B. DeWitt, ed., The Environment and the Christian: What does the New Testament say about the Environment? Grand Rapids: Baker Book House, 1991.

Zerbe, G. "The Kingdom of God and Stewardship of Creation," dalam C.B. DeWitt, ed., The Environment and the Christian: What does the New Testament say about the Environment? Grand Rapids: Baker Book House, 1991. 